\title{
ISR đón sớm thập niên mới với chủ đề tài chính khởi nghiệp trên Springer Nature
}

\author{
Nguyễn Thanh Huyền \\ Trung tâm ISR \\ Trường ĐH Phenikaa
}

Hà Nội, ngày 3 tháng 11 năm 2020

Năm 2021 đánh dấu sự bắt đầu của thập niên thứ 3, thế kỷ 21. Bên cạnh những thách thức lớn toàn cầu về an ninh lương thực, biến động hệ sinh thái, đổ vỡ khí hậu, còn có những thay đổi lớn của kỷ nguyên số và bình minh Cách mạng công nghiệp 4.0.

Lực lượng khởi nghiệp toàn cầu sẽ tiếp tục hành trình nào và giúp định hình nền kinh tế toàn cầu trong bối cảnh đầy bất trắc ra sao?

Đây là những câu hỏi lớn và cần có sự kiểm đếm lịch sử, học hỏi từ kinh nghiệm, kiến thức và trí khôn của nhiều thế hệ học giả.

Trung tâm ISR vinh hạnh được đóng góp trong số tạp chí khai trương 2021 của Springer Nature Business \& Economics (ISSN: 2662-9399), với nghiên cứu có tựa đề "On the social and conceptual structure of the 50-year research landscape in entrepreneurial finance" (doi: 10.1007/s43546-020-00002-z).

\section{Springer Link}

Review Article | Published: 02 November 2020

On the social and conceptual structure of the 50-year research landscape in entrepreneurial finance

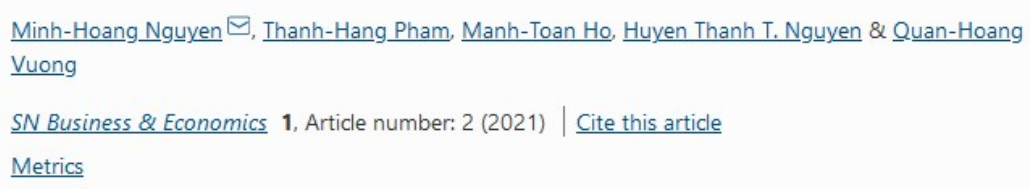

\author{
Download PDF \\ Sections \\ Figures \\ Abstract \\ Introduction \\ Materials and methods \\ Results \\ Discussion and conclusion \\ Data availability \\ Code availability \\ References \\ Funding \\ Author information \\ Ethics declarations \\ Rights and permissions \\ About this article
}




\section{https://link.springer.com/article/10.1007/s43546-020-00002-z}

Bài nghiên cứu rà soát lịch sử 50 năm ngành tài chính khởi nghiệp, bằng cách kết hợp phương pháp bibliometrics với lăng kính lịch sử chính trị xã hội của nhân loại. Phạm vi nghiên cứu trải khắp không gian toàn cầu, và bao phủ các địa hạt quan trọng nhất của lĩnh vực có ảnh hưởng cốt lõi: tài chính khởi nghiệp.

Trong nghiên cứu, hầu hết các tên tuổi, tác phẩm và các trung tâm tri thức làm nên những mốc lịch sử quan trọng của ngành cũng được kiểm đếm, với tinh thần làm nên một xuất bản phẩm giàu chất suy nghĩ, có đóng góp lý thú, và có tính định hướng nghiên cứu lâu dài.

Với quan điểm về đầu tư nghiên cứu hiệu quả như một đóng góp làm giảm chi phí khoa học lâu dài, Trung tâm ISR trân trọng giới thiệu bài tới cộng đồng nghiên cứu quan tâm tới khởi nghiệp, một hoạt động có tính chất trái tim của kinh tế thị trường suốt nhiều thế kỷ qua.

\section{References:}

Minh-Hoang Nguyen, Thanh-Hang Pham, Manh-Toan Ho, Huyen Thanh T. Nguyen \& QuanHoang Vuong. (2021). On the social and conceptual structure of the 50-year research landscape in entrepreneurial finance. SN Bus Econ, 1(1):2.

Quan-Hoang Vuong. (2018). The (ir)rational consideration of the cost of science in transition economies. Nat Hum Behav, 2(1):5. 